\title{
TRI HANAKARA AS A SPATIAL LAYOUT PERSISTENCE CONCEPT OF BALUWARTI SETTLEMENT IN SURAKARTA
}

\author{
Tri Hartanto ${ }^{13 *}$, Tony Atyanto Dharoko ${ }^{1}$, Yoyok Wahyu Subroto ${ }^{2}$ \\ ${ }^{1.2}$ Department of Planning and Architecture Engineering, Engineering Faculty, UGM Yogyakarta \\ Grafika Street No.2 UGM Campus, Yogyakarta 55281 Phone 0274542973 \\ ${ }^{3}$ Architecture Study Program, Engineering Faculty, Tunas Pembangunan University of Surakarta \\ Walanda Maramis Street No.31 Cengklik Surakarta 57135 Phone 0271853824 \\ *Corresponding author; Email: tri.hartanto23@yahoo.com
}

\begin{abstract}
Elements of settlement spatial layout (physical aspect) and community’s social-cultural life with any rites (non-physical aspect) are still performed by some people in Baluwarti Settlement until today, leading to a distinctive peculiarity. It is this peculiarity that makes Baluwarti Settlement environment located inside the court (palace) different from other settlements (outside the court) in Surakarta. Considering the qualitative research paradigm and historical reading method, this research could find out that the spatial layout concept of Baluwarti Settlement namely Tri Hanakara. In which the kings reigning after Paku Buwana III constructed this Baluwarti settlement to forward the previous King's wish.
\end{abstract}

Keywords: Concept; spatial layout; Baluwarti settlement.

\section{INTRODUCTION}

The main building of Kasunanan Surakarta Hadiningrat has been built by Paku Buwana II (17421749). Having the main court been constructed completely, Paku Buwana II passed away, and succeeded by Paku Buwana III (1749-1788), with degree Sinuwun Kanjeng Susuhunan Prabu Amangkurat Jawa Senapati Ing Ngalaga Abdurrahman Sayidin Panata Gama Khalifatullah Ingkang Kaping III Ing Negari Surakarta Hadiningrat (Purwadi, 2007:405). Then, during his early reign, Baluwarti settlement started to be constructed (as the dwellings for sentana dalem and abdi dalem) serving as the defense fort all at once.

The background of Baluwarti settlement construction departed from the people's formal bond to the Court. This formal bond constitutes the status as abdi dalem of court, with a degree or kekancingan conferred by Sinuwun. This presence of settlement originally functions as kingdom city (kuthagara) as the governmental center of Kasunanan Surakarta Hadiningrat palace. The dwellings in this settlement are classified by the status, role, and rank (position) of individual dwellers.

Kasunanan Surakarta Hadiningrat Palace is the source of Javanese culture or Kejawen as the Javanese Queen ancestor's heritage, since Mataram Palace time. Therefore, Surakarta Palace has cultural value and historical values that have passed through a long historical track. Surakarta Hadiningrat Palace keeps existing either de facto or de jure, as the original Indonesian state form heritage of Javanese Culture in its historical journey over 270 years (Winarti, 2002: $61)$.
In the development stage, after Paku Buwana III period with Baluwarti settlement, other groups of settlements began to be constructed: (a) Sekullanggen, (b) Hordenasan, and (c) Gambuhan. There are also Lumbung Wetan and Lumbung Kulon dwelling groups in charge of dealing with food stock at that time. In addition to dwellings for abdi dalem and sentana dalem, dalem pangeran was also constructed in Baluwarti settlement area. The number of dalem pangeran is substantial in Baluwarti area, and the presence of dalem pangeran still can be witnessed until today despite some damaged condition. There is a dwelling group for abdi dalem catering to pangeran surrounding the dalem pangeran area. Then, Paramasana mosque was also constructed in Baluwarti, exactly in the west of Kori Brajanala Utara in the north of the area. In addition to the mosque, market building and horse stall were also constructed, called Langensari.

Baluwarti settlement area located inside Baluwarti fort encircles the main area of Surakarta Hadiningrat palace concentrically. Recently, the condition of Baluwarti settlement (during PB.XIII period) is very crowded. Baluwarti settlement began to be constructed by Paku Buwana III, at that time the dwelling area constructed was the one for Tamtama, Carang, and Wireng soldiers. So, in its original condition, many lands were empty in Baluwarti Settlement. Recently, many masjids (mosques), schools, and Kelurahan Baluwarti office have been constructed there. Kelurahan Baluwarti Office was built in the post-independence period. And the function of Kelurahan office is limited to catering to Baluwarti settlement and the palace's citizens in the terms of demographic and governmental adminis- 


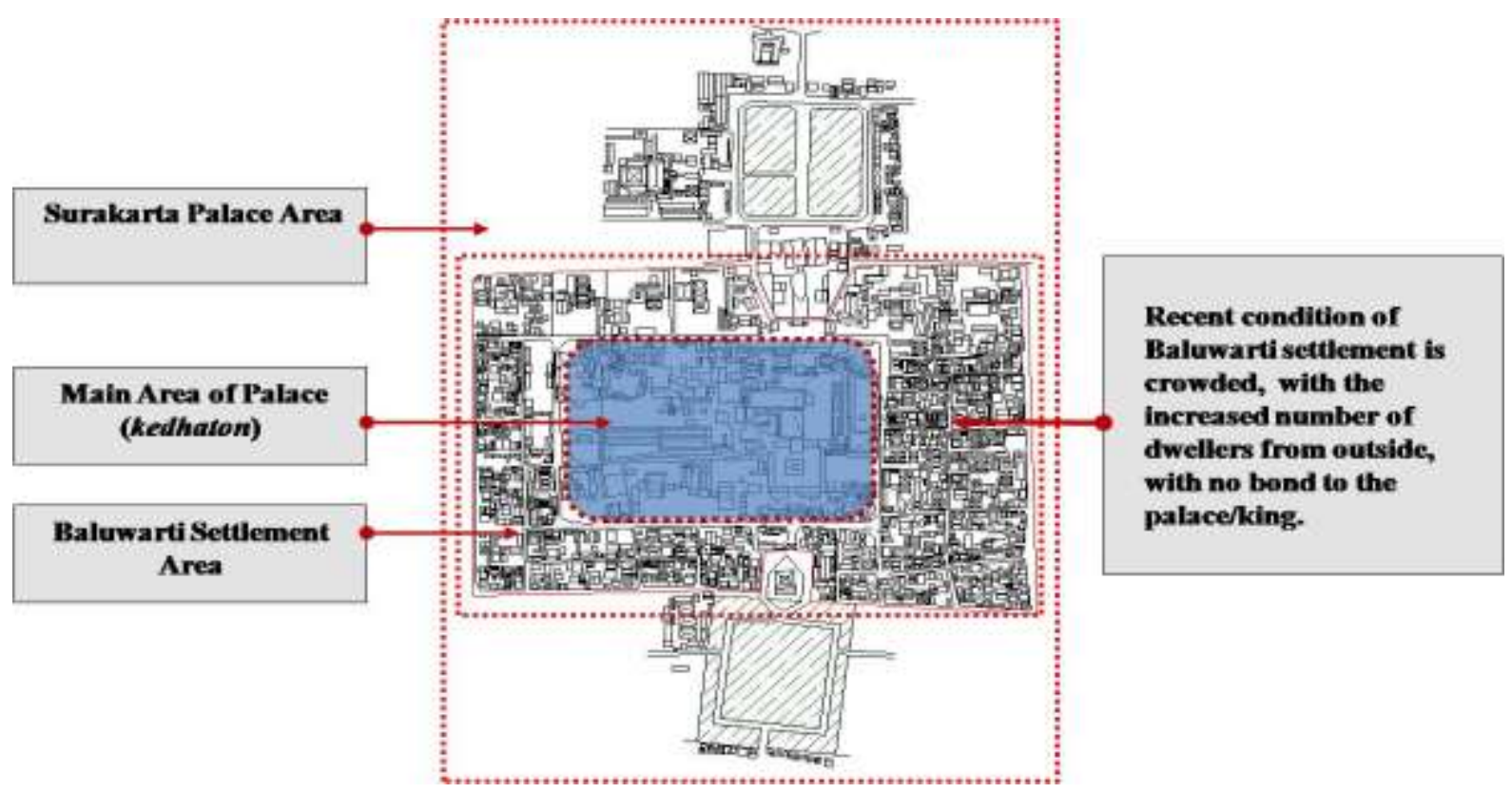

Fig. 1. Baluwarti Settlement Area as a part of Surakarta Hadiningrat Palace area (Source: Surakarta Palace's Literature, 2004: 38)

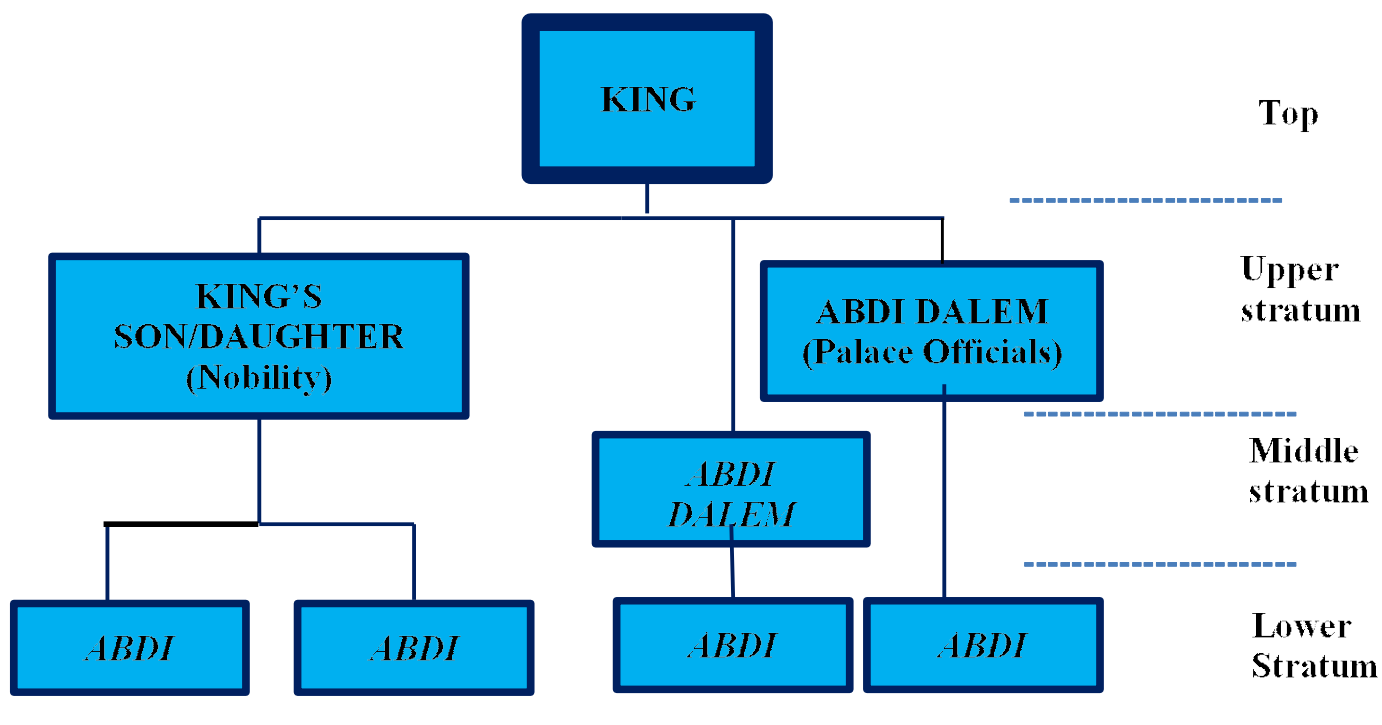

Fig. 2. Scheme of Society's Social Strata in Baluwarti (Source: Farkhan, 2002)

tration. Then the number of abdi dalem dwellings increases, because many abdi dalem's relatives/ families come to stay in Baluwarti settlement's environment. As suggested by KGPH Dipokusumo, the palace cannot preclude the increased number of people coming and staying in Baluwarti.

Most Baluwarti citizens still have a relationship with the Palace, as either abdi dalem or sentana dalem. The people having a relationship with the palace still always undertake custom and tradition according to their ability. Thus, court tradition and culture cannot disappear easily and, one of which is magersari system still being the bond between abdi dalem and the court (palace).
The social-cultural life of Baluwarti people is inseparable from the historical background of the settlement environment establishment. As a vehicle accommodating people's life Baluwarti originally is an integral part of Kasunanan Surakarta Palace. Members of Baluwarti community are closely related to the social-cultural condition of the community residing in the area. The members of the community here are inseparable from the existence of Kasunanan Surakarta Palace. On the other hand, the Palace is a global citizen. Nevertheless, genius loci is still found, being the characteristics of Baluwarti settlement environment. 


\section{METHOD}

Considering the background, question, and objective of the research, to find out the spatial layout concept of Baluwarti settlement, the research method chosen in this study was the one that can formulate a local (idiographic) concept. In this case, this research aimed to identify not only the spatial layout of Baluwarti settlement physically but also the concept underlying the physical embodiment of Baluwarti Settlement's spatial layout. Such concept is believed to be affected by the traditional and cultural values of Surakarta Palace. The context of the court's traditional and cultural values can be captured not only by five senses and logic but also by mind/feeling (ethic) and with creed or belief (transcendental).

A qualitative research method, according to Sugiono, (2014:1), is the one building on postpositivism, used to study the condition of the natural object (the opposite is an experiment) in which the author is key instrument, data source (informant) sampling is conducted purposively, data collection technique is conducted with triangulation (mixed), inductive/qualitative data analysis, and the result of the qualitative research emphasizes more on meaning than on generalization. Considering the research method approach by considering the empirical condition of the research object and research question formulated, this research conducted referred to postpositivism paradigm. Meanwhile, the research method used was historical studies with historical reading. Historical studies are used to find out the early concept of Baluwarti settlement's spatial layout constructed, through books or babad telling about the condition at that time, document/archive/ magazine/article, and newspaper, picture in that period, and artifact still existing. Thus, it can be used to see the elements of Baluwarti Settlement's spatial layout still surviving until today. Furthermore, an inductive qualitative approach with the in-depth interview was used to reveal the factors affecting the society still holding tightly on traditional and cultural values as the elements composing the typical characteristics of Baluwarti Settlement's spatial layout.

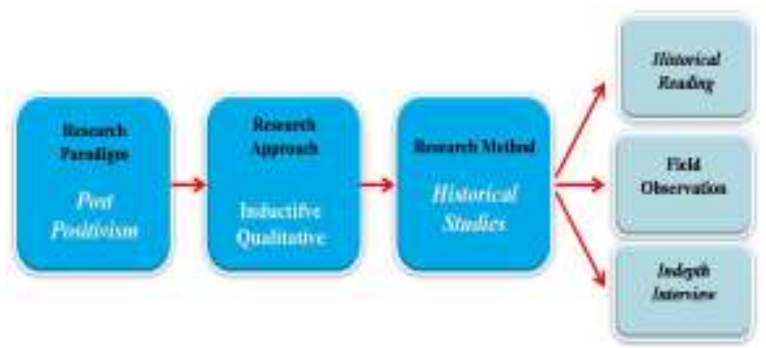

Fig. 3. Research Paradigm, Approach, and Method

\section{THEORETICAL STUDY}

Wikantiyoso in Krisna (2005: 17) explained that traditional settlement is the regional asset that can give the environment a characteristic and an identity. The regional identity is composed of environment patterns, fostered village formation, characteristic of social-cultural activity, and typical economical activity. The settlement's spatial layout pattern contains three elements: a) space with its composing element (building and space surrounding), b) formation with composition meaning, and c) a composition's pattern or model. Traditional settlement pattern, by its distribution pattern, is also divided into two: dispersal and colony patterns.

In traditional culture, the form of settlement is faced with ritual organization background, basically aiming to organize the formation harmoniously. Putra (2005:5) suggested two basic organization systems in traditional spatial concept, the geometric organization connected to ritual and cosmological matters.

The cosmology concept is defined as a belief in the presence of a harmonious relationship between jagad cilik (microcosm) and jagad gede (macrocosm). Microcosm is a reflection of human world, while macrocosm is universe. In relation to traditional architecture (including settlement), most buildings are the secular representation with heavenly image, unifying the axes of jagad cilik and of jagad gede, revealing magic orientation direction, etc (Rapoport, 1969). Then, the building is explained to be the metaphor of social situation, context, and chart, in the form of symbolism, reflected on objective and measurable energy aspect, based on its dweller community.

Traditional Javanese community still believes in the presence of "central" power in the form of Palace (Court), the King's residence. King and his court are symbolically considered as a place to bind themselves. Traditional Javanese community feels having no self-existence if they do not bind themselves to the kingdom. Kingdom in such bond is often called the cultural center. The form of the Javanese community's self-bond can be manifested into following anything adhered to, done, and being the life order and value order in kingdom environment, for example, language, the custom procedure of commemorating birth, wedding, death, fashion, and even building a house. Considering the background of belief, a Javanese "settlement" with the imaginary center was created (Junianto, 2016). The center is the king or the symbolic manifestation of a king. 


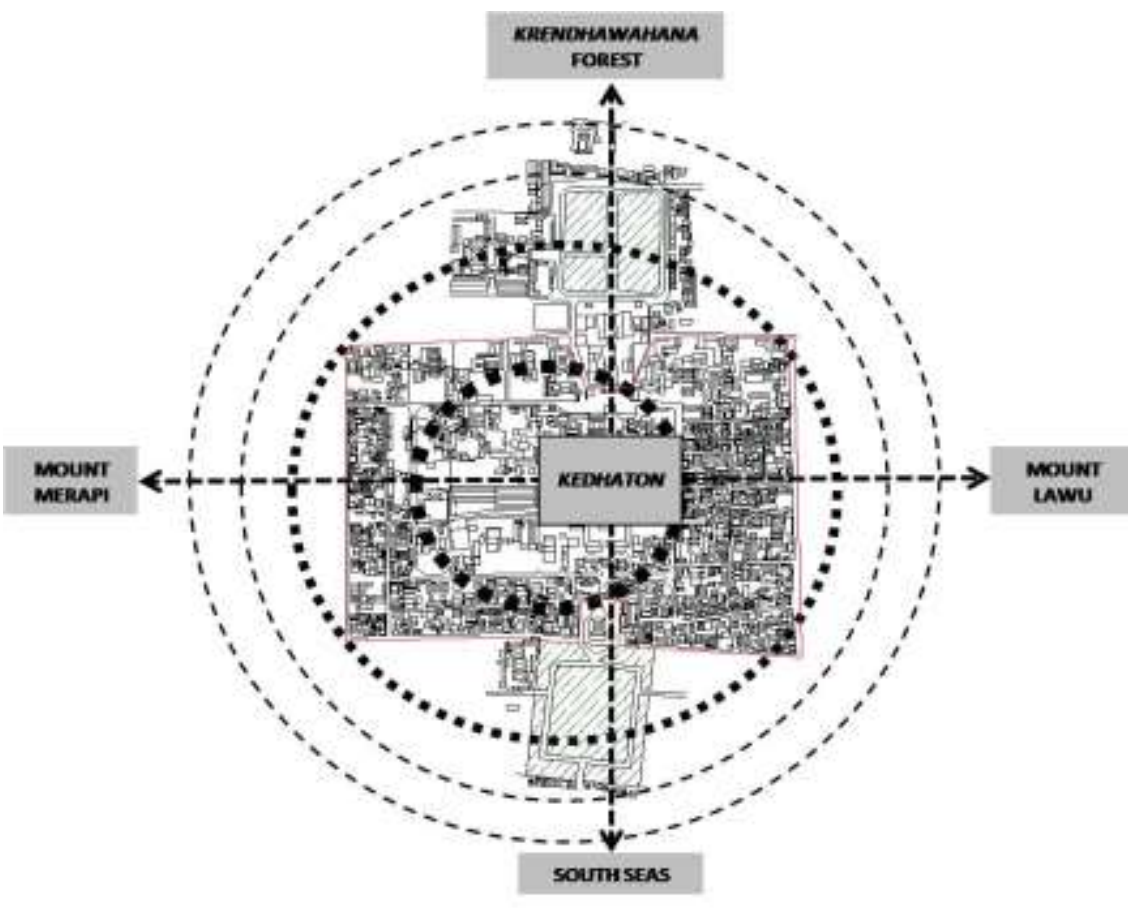

Elements composing spatial layout:

a. Zoning

b. Regional orientation

c. Axis

d. Building layout

e. Model/pattern

f. Society System

Concept underlying the creation of spatial layout:

a. Cosmology Concept

b. Sedulur papat lima pancer Concept

c. Hierarchy/Sacredpropane

d. Dualism

e. Dwelling pattern concept

f. Radya Laksana Concept

Fig. 4. The Manifestation of Baluwarti Settlement's Spatial Layout, Elements Comosing, and Concept Underlying

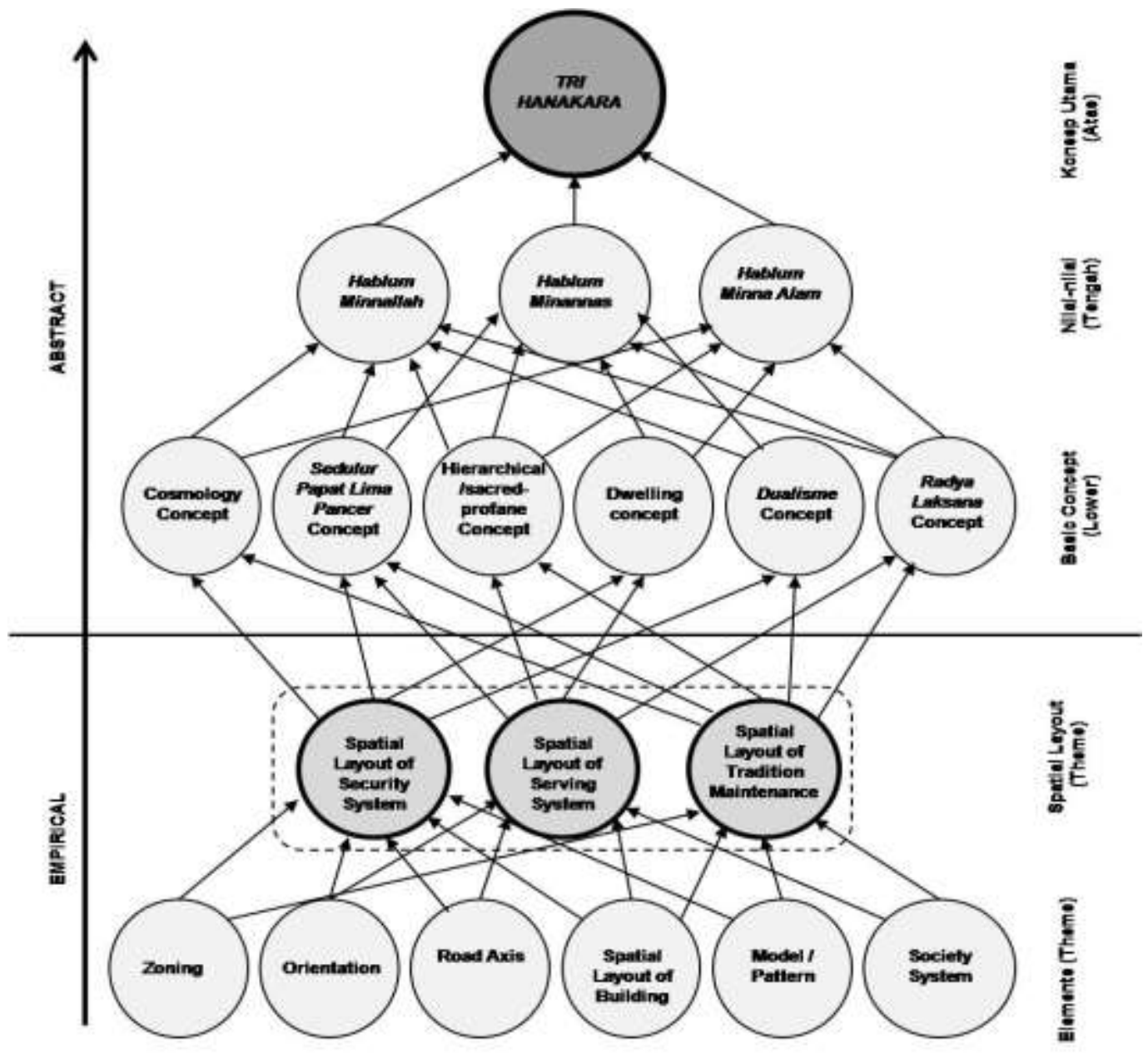

Fig. 5. Process of Formulating Main Concept Underlying the Manifestation of Baluwarti Settlement's Spatial Layout in Surakarta (Source: analysis, 2017) 
Based on Kostof's theory, according to Kusumastuti, (2016:33), the form of urban space organization as the center of Javanese Court kingdom indicates the characteristics of the Holy City model, including (1) monumental axis in Javanese Court concept manifested into Kiblat Papat Lima Pancer concept, (2) encircling wall and gate in Javanese Court concept manifested into fort and pole, (3) dominant landmark in Javanese Court concept manifested into alun-alun (city square), masjid (mosque), palace, and market, and (4) regular and hierarchical grid pattern in Javanese Court concept manifested into the cosmological structure of urban space with social structure-based hierarchy.

\section{RESULT AND DISCUSSION}

The process of formulating the spatial layout concept of Baluwarti settlement is the on of abstracting from the manifestation of Baluwarti settlement's spatial layout maintained since Paku Buwana III - Paku Buwana XIII periods along with other concepts underlying its embodiment. This formulation process is based on the discussion in the previous chapter, that has identified the embodiment of Baluwarti settlement's spatial layout along with its various elements of spatial layout, as a basis to formulate the concepts underlying the embodiment of settlement's spatial layout. The original concept of Baluwarti settlement's spatial layout constructed during Paku Buwana III's reign was manunggaling kawula - gusti. This concept is the manifestation of serving the king, preserving tradition and culture, and creating safety that can be brought into reality when there is an integration and togetherness between the king and his people/kawula.

The spatial layout concept of Baluwarti settlement can be viewed from its composing elements. Overall, the spatial layout elements of the settlement are divided into two: non-physical and physical. The non-physical element of area consists of (1) creed/religion; although Islamic nuance has colored the cultural symbols of Kasunanan Surakarta court, in fact, its community's religious behavior and attitude still indicate syncretistic Islam characteristic. A variety of Pre-Islam creeds like believes in heirloom power, in ancestor spirit, in the invisible creature, and other pre-Islam rites were an integral part of Baluwarti's religious life, (2) politics and safety; to support the king's rule, Paku Buwana III made the region surrounding the Court the defense area. The region surrounding the Court is called Baluwarti, functioning to be the population settlement with magersari system, particularly those with kinship to the king, and people serving the king, (3) social and culture; generally social status of Baluwarti community, in addition to deriving hereditarily from their genealogy, the social status of Surakarta Palace's nobility. Each of the community members has their own right and obligation according to status and degree specified by the Court (King), (4) economic; some community members were traders, limited to fulfilling daily needs. Thus, the people (kawula) worked as necessary only. The economic system is limited to the fulfillment of primary/life needs. Although Baluwarti settlement at that time as kingdom city (kuthagara), however, the economic system is still very simple, (5) traditional and cultural values; that in principle, Surakarta Palace's culture is Islamic, but in the property used for implementing the court rite or tradition is inseparable from Hindu culture still existing until today, the belief in the equality and reciprocal relation between macrocosm and microcosm, with the king being the center of microcosm.

Physical elements of area composing the spatial layout of Baluwarti settlement are (1) building and space surrounding, consisting of Baluwarti fort, gridshaped road network, kedhaton orientation, kori brajanala lor and kori brajanala kidul, abdi dalem settlement classified by profession and duty, and $\mathrm{Ki}$ Gede Sala's grave. (2) composition; the composition of the region is affected by sedulur papat lima pancer concept. The composition of the settlement area consists of North (front), East and West (side), and South (back). Meanwhile, kedhaton as the center/ pancer of four directions (sedulur papat). (3) model (pattern); the model shape pattern of Baluwarti settlement is encircling and oriented to kedhaton, as the King's position. It indicates the close relationship between the settlement area and kedhaton. Thus, this settlement development was devised to encircle kedhaton area settlement concentrically. (4) Baluwarti settlement land/area is located in the second circle; the court's territory is divided concentrically, according to Behrend (1982), in which the second circle still has a high magic aura, as it is fairly close to the first circle, kedhaton. The location in the second circle indicates that this settlement has a strong magic aura as it is close to the king. (5) society; people living in Baluwarti settlement are those wanted by the king, and they serve their life to the King.

Concepts underlying the survival of Baluwarti Settlement's spatial layout are the manifestation of the community's awareness of idea to achieve life harmony and conformity originating from Javanese (court) cultural values inspired with Islam religious tenets. The values of the basic concept include 
hablum minnallah, hablum minannas, and hablum minna alam called Tri Hanakara.

The existence of the court's traditional and cultural values in Tri Hanakara concept still maintained until today can be seen from the maintenance of elements composing the spatial layout of Baluwarti Settlement during Paku Buwana III - Paku Buwana XIII periods. Considering the result of the diachronic analysis, it can be found that the original concept of Baluwarti's spatial layout is continued and maintained by the following kings.

The awareness of togetherness and unity between the king and his people in maintaining the relationships between human and good, between humans, and between human and surrounding nature is believed by Baluwarti community to create life harmony and conformity in the world and hereafter.

Suparno, (2017) explained that the legal culture of Surakarta Court is still existing until today, despite many challenges in this present era. At least sentana dalem and abdi dalem still undertake it. Even the elder generations who have experienced the existence of court surely still believe in it. The belief in equality and reciprocal relation between macrocosm and microcosm, with the king being the center of microcosm, has generated customary ceremony traditions in Surakarta court that is official in nature such as Grebeg, Kirab, and Jamasan Pusaka, Labuan, Nyadran, Mahesalawung, Tingalan Jumenengan Dalem, and Pasowanan Ngabekten. The customary ceremony created by Surakarta Palace's poet implies various meanings in each of its details. The main objective of the ceremony is to put each of the community members onto certain social position as king, sentana, abdi dalem and kawula (Kuntowijojo, 1987:40-41). The followings are ceremonies or rites involving the relation between king, sentana dalem, abdi dalem and kawula/ Baluwarti people (Santoso, 2017):

- Grebeg/sekaten; this tradition is maintained and undertaken continuously in the attempt of presserving the meaningful ancestor traditions.

- Kirab and Jamasan Pusaka; kirab and jamasan pusaka to Baluwarti people are to undertake ancestor tradition and culture, and is defined as a ceremony containing Javanese philosophical value, manunggaling kawula ing Gusti.

- Tingalan Jumenengan Dalem; tingalan jumenengan dalem is a ceremony to commemorate the king's inauguration.

- Pasowanan Ngabekten; pasowanan ngabekten rite presupposes the service and request for king's bless.

- Considering the explanations given by elders in Baluwarti (2017), in addition to the court's large- scale ceremony/tradition, most Baluwarti people still undertake the small-scale ones originating from the Court, constituting a belief still held on tightly until today including, among others:

- Caos dhahar, putting the flower into a small cup in the sacred places, such as in the pillar of joglo house, and in Ki Gede Sala's grave.

- Bucalan; sesaji / sajen (offering) prepared during the wedding event, put onto four comers of a settlement area, and in T-intersection and intersection considered as sacred.

- Mubeng beteng; mubeng beteng (cempuri) is conducted by parents wanting something for their children, hoping that their children will achieve their ideal (what they want). It is conducted because there is a belief and in the Court, there are some heirlooms with magic power as the intermediary to God.

- Dhudhuk lumpur, to maintain the bond with king, by paying tax, undertaking pisowanan on Thursday and Islamic Holy Day (Eid el Fitr).

The rites still conducted by Baluwarti people until today are a creed/belief in values contained in the tradition and culture. These creeds and beliefs are undertaken in the attempt of achieving life harmony and comfort in the world and to achieve true happiness in the hereafter. Javanese cultural tradition and Islam tenet are undertaken consciously, sincerely, and faithfully.

The concept underlying the survival of Baluwarti settlement's spatial layout is Tri Hanakara. This spatial layout concept is inseparable from the concepts underlying it such as 1) cosmology, 2) sedulur papat lima pancer, 3) hierarchy, 4) dualism, 5) dwelling pattern, and 6) radya laksana. Then, considering the result of the analysis, those concepts build on the manifestation of the values of maintaining and establishing life conformity that can be brought into reality due to the well-maintained relations between human and Allah SWT (hablum minnaallah), and between humans (hablum minnannas), and between human and nature. King and most Baluwarti people still hold tightly on these principles in life as the way of life.

Generally, these six concepts underlie Tri Hanaraka concept becoming the concept of Baluwarti Settlement's spatial layout survival. These six concepts, in more detail, becomes the manifestation of Baluwarti Settlement's spatial layout, including cosmology, territorial division, dwelling concept, accessibility concept, axis, circulation, composition (formation), and dwelling model/pattern. It can be identified as follows: (a) cosmology concept; most 


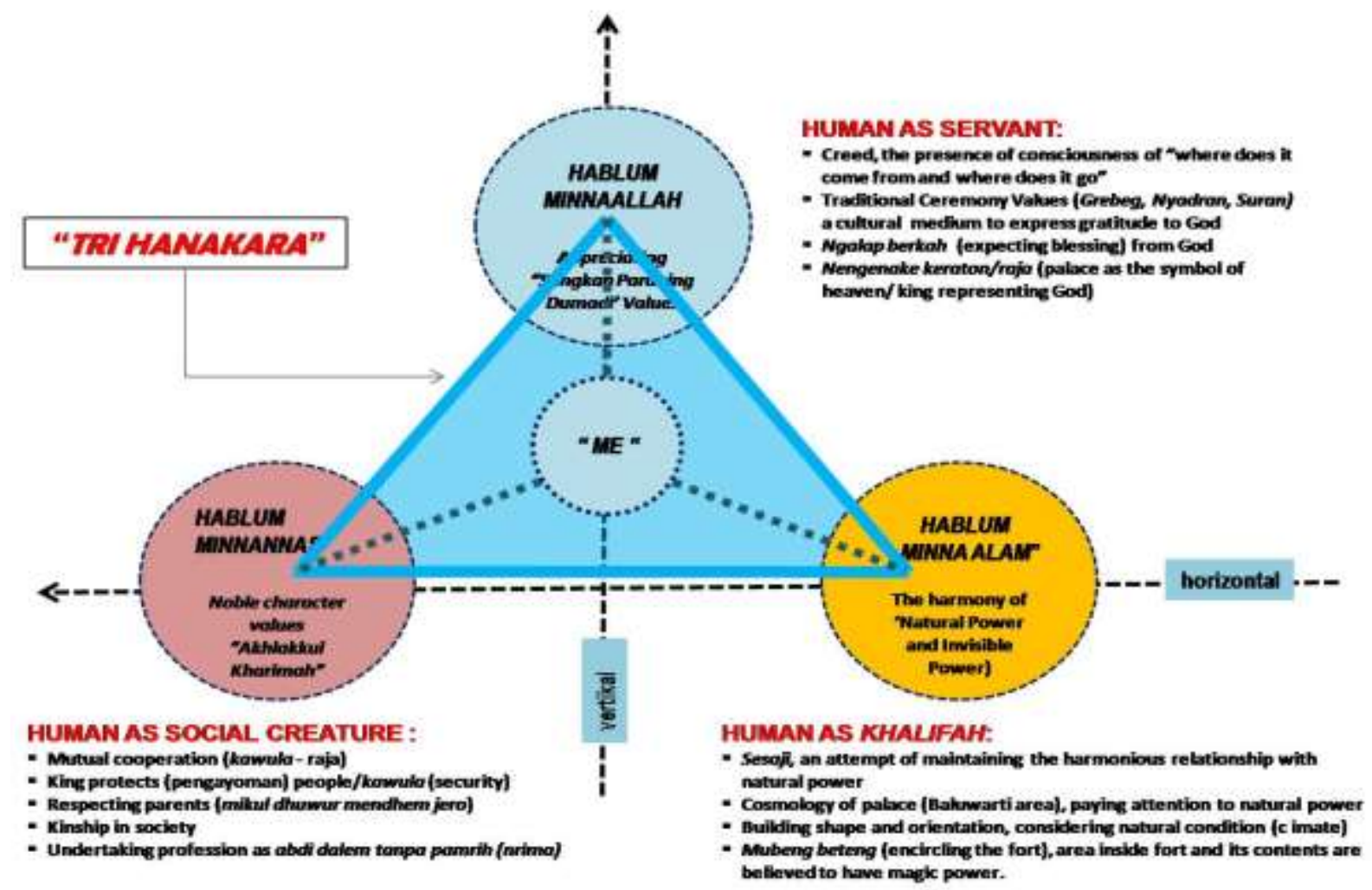

Fig. 6. Tri Hanakara Concept as the Baluwarti Community's Consciousness of Maintaining the typical characteristics of Settlement's Spatial Layout (Source: Analyst, 2017)

Baluwarti people still believe in the natural power affecting the spatial layout of settlement; (b) territorial division; in the North, East, South, and West sides; (c) dwelling concept; kedhaton (king) is located in the center of area, dwelling layout, dalem pangeran is in the first circle/close to kedhaton (King), while abdi dalem is in the second one, (d) accessibility; originally there are two points, entrance in the North and exit in the south; (e) axis; the axis of region extends from the North to the South, the layout of Kori Brajanala Utara (sangkan/ origin of human beings) toward Kori Brajanala Selatan (paraning/human's final end or objective); (f) circulation; the main circulation in the region rotates clockwise, kawula and abdi dalem ngengenaken raja (respect the king); (g) formation; masjid (mosque) located in the North (North West) of region, Ki Gede Sala's grave in the North (North East), the soldiers (king's guard)'s dwelling is in the East, rice barn in the South, horse stall in the South and Market is in the West (South West), all buildings encircling and oriented to the court; (h) model/pattern; generally, the dwelling model is in group (colony) and roads existing create grid pattern, the prince's house (dalem pangeran) is big Joglo, completed with pendapa, peringgitan, dalem ageng, and a series of supporting building on the right and left sides of it, even sometimes a broad yard is constructed in front of the main building encircled with sufficiently tall wall and equipped with the gate in the middle, the shape of sentana dalem' house is Limasan, while that of abdi dalem/kawula's is Kampung.

Some embodiments revealing the objective of Tri Hanakara concept can be identified from the spatial layout of Baluwarti Settlement, Surakarta:

a) The location of Masjid Paramasana/Suranatan is in the north, exactly in the west of Kori Brajanala Lor, in which the sacred area is located. This masjid is still used by Baluwarti and surrounding people to do worship. This masjid mainly functions to be a place for pray (sholat), in which sholat is a means for human to do worship directly and vertically to Allah SWT (hablum minnaallah). In addition, it is also used as the place for the people to do muamalah/to interact with Baluwarti community members and surrounding people (hablum minannas).

b) Dalem Pangeran Sasana Mulya is located in the north of the region, indicating the sacred and respected area. Dalem Pangeran Sasana Mulya has been constructed since Paku Buwana IV's reign. In addition to functioning as the house of prince later to be the King's successor, in this neighborhood just like in other dalem pangeran, there are dwellings for abdi dalem, exactly in the 
right, left sides, and behind it, in charge of catering on all needs of dalem pangeran's dwellers. Thus, the relationship is established between abdi dalem and pangeran, just like between kawula and Gusti. Such relation in the context of kawula-Gusti relationship can be defined as vertical relation (hablum minnaallah) between human and God. Besides, there is a reciprocal relation between pangeran and abdi dalem in the context of horizontal relationship constituting hablum minannas.

c) Pasar Anyar is located in the West (Northwest) on East-West Axis, in which traditionally, it is located in the profane area. Pasar Anyar (New Market) constructed during Paku Buwana X's reign is an element of the settlement's spatial layout still maintained by Baluwarti people until today, although in recent condition, many spaces of market are used for dwelling. Market is the place where seller and buyer meet, where a human sees another. Such interaction belongs to horizontal relation (hablum minannas). d) Ki Gede Sala's Grave is located in the North (Northeast) on the North-South Axis traditionally called sacred place. The existence of Ki Gede Sala's grave is highly respected by Baluwarti people and surrounding. In such context, Baluwarti people believe in the presence of other (metaphysical) power or spirit defined as a natural power. This spirit power is believed to exist in Baluwarti settlement area. Thus, some members of the community still caos dhahar and sesaji (give offering) in certain places considered as the place of pengusan/spirit. It is intended to avoid some disaster from befalling an individual not believing in it. Therefore, such belief is still maintained by some of Baluwarti people, this context of relation is called hablum minna alam or maintaining harmony and conformity with "natural power".

e) Other elements of spatial layout such as circulation pattern (pradaksina), North-South and EastWest axes, dwelling, formation, and model/pattern

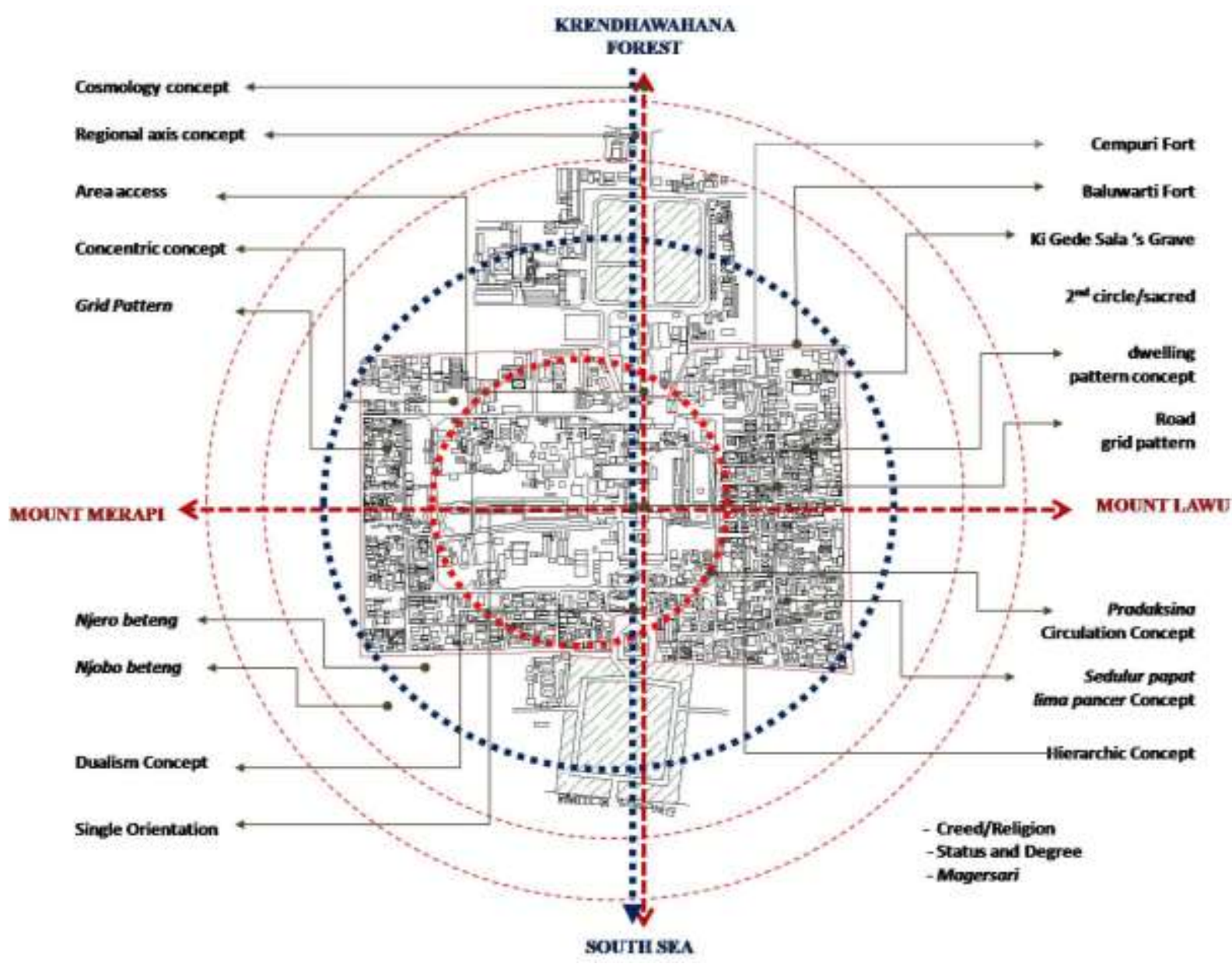

Fig. 7. The Content of Tri Hanakara Concept in the Survival of Baluwarti Settlement's Spatial Layout in Surakarta (Source: Analysis, 2017) 
of settlement, are believed to be the manifestation of the maintenance of harmony and conformity with nature, implemented into daily activities. Overall, it can be classified into three relations: hablum minnallah, habulum minannas, and hablum minna alam.

\section{CONCLUSON}

The manifestation of Baluwarti settlement's spatial layout today is the continuation of its early spatial layout during Paku Buwana period. This spatial layout is affected by Surakarta Palace's interest in creating defense and security, king-serving, and tradition preservation systems. Thus, this spatial layout is affected by and continues the Mataram lineage's tradition, such as: location of king's guard (soldier)'s dwelling in the East, masjid in the North (Northwest), dalem pangeran close to the King, North-South (sacred) and East-West (profane) axes. Then, buildings existing inside the area are oriented to kedhaton (king's residence).

The manifestation of Baluwarti Settlement's spatial layout in Surakarta implies the awareness of idea originating from values and objective to be achieved by king and court family, and people living in Baluwarti settlement. In this case, the manifestation of Baluwarti settlement's spatial layout with a variety of elements, including physical/non-physical elements, and lineage concept builds on the people's awareness of idea to achieve Tri Hanakara, the conformity with environment, the harmony in social life based on creed/belief values. Tri Hanakara is human's guidance and life objective as an individual and social creature, manifested into a variety of behaviors, formations, rules, activities, and human activity organization. Tri Hanakara is a transcendental value that has been recognized and known by Baluwarti people in Surakarta, thereby affecting many activities and the manifestation of community's activities. Each of community activities is a process and a means of achieving conformity, harmony, and wellbeing for all members of the community. It is reflected in the people's attempt of maintaining a harmonious relationship with God, with fellow humans, and with the universe. God is recognized to the Almighty determining a variety of community activities to achieve conformity, harmony, and wellbeing in life in both world and hereafter.

\section{ACKNOWLEDGMENT}

This paper is a part of the author's dissertation, in Universitas Gadjah Mada (Gadjah Mada
University) of Yogyakarta. For that reason, the author would like to express his gratitude to all of those supporting this study. He also would like to say thank to the informants for information, data, and time devoted to this study. The author also expresses his big thank to promoter and co-promoters.

\section{GLOSSARY}

\begin{tabular}{|c|c|}
\hline Abdi Dalem & $\begin{array}{l}\text { retainers; courtiers; member } \\
\text { of the royal household }\end{array}$ \\
\hline Alun-Alun & $\begin{array}{l}\text { great field in front of a } \\
\text { Karaton: court; ruler's } \\
\text { residence }\end{array}$ \\
\hline Beteng Baluwarti & $\begin{array}{l}\text { inner wall surrounding the } \\
\text { Karaton: court; ruler's } \\
\text { residence }\end{array}$ \\
\hline Dalem Pangeran & aristocratic mansion \\
\hline Kedhaton & inner court \\
\hline Kekancingan & aristocratic rank; title \\
\hline Karaton & court; ruler's residence \\
\hline Kawula & $\begin{array}{l}\text { followers; (the) people; } \\
\text { citizens }\end{array}$ \\
\hline Kori & gate \\
\hline Kori Brajanala Lor & $\begin{array}{l}\text { name of the main gate } \\
\text { leading to and from the } \\
\text { court's front yard }\end{array}$ \\
\hline Kori Brajanaka Kidul: & $\begin{array}{l}\text { southern gate giving access } \\
\text { to Sitihinggil Kidul }\end{array}$ \\
\hline Lawang : & gateway; door \\
\hline Lawang Gapit Wetan : & $\begin{array}{l}\text { Baluwarti's eastern entrance } \\
\text { gate }\end{array}$ \\
\hline Lawang Gapit Kulon: & $\begin{array}{l}\text { Baluwarti's western entrance } \\
\text { gate }\end{array}$ \\
\hline Negoro/Negari & land; country; realm \\
\hline Negorogung & $\begin{array}{l}\text { rural areas surrounding the } \\
\text { capital }\end{array}$ \\
\hline Pradaksina & to circumambulate clockwise \\
\hline Prajurit Dalem & royal armed force \\
\hline Probosuyoso & $\begin{array}{l}\text { name of the central, inner } \\
\text { path of Javanese building }\end{array}$ \\
\hline Sentana dalem & $\begin{array}{l}\text { relative and in-law of the } \\
\text { ruler }\end{array}$ \\
\hline
\end{tabular}

\section{REFERENCES}

Achmad, S.W. (2016). Babad Giyanti: Palihan Nagari dan Perjanjian Salatiga, Araska, Yogyakarta

Bakker, A. (1995). Kosmologi dan Ekologi. Kanisius Yogyakarta.

Budihardjo, E. (1997). Jati Diri Arsitektur Indonesia. Alumni, Bandung.

Creswell, J. (2014). Penelitian Kualitatif Dan Desain Riset. Pustaka Pelajar. Yogyakarta 
Goulding, C. (1999). Grounded Theory: Some Reflections on Paradigm, Rocedures and Misconceptions. Working Paper Series June 1999. ISSN 1363-6839. University of Wolverhampton, UK.

Hardiyanti, N.S. (2005). Studi Perkembangan dan Pelestarian Kawasan Keraton Surakarta, jurnal Dimensi Teknik Arsitektur, 33(1), 112- 124.

KRMH. Y. (1994). Karaton Surakarta Hadiningrat, Bangunan Budaya Jawa sebagai Tuntunan Hidup/Pembangunan Budi Pakarti Kejawen. Macrodata Solo.

R.Ng. P. (1939). Pustaka Radya Laksana, Budi Utama, Surakarta, Copyright (C) 2011-13 Yayasan Sastra Lestari.
Rapoport, A. (1969). House, Form, and Culture, Prentice Hall Inc, London.

Soeratman, D. (1989). Kehidupan Dunia Keraton Surakarta 183-1939, Taman Siswa, Yogyakarta

Straus, A. \& Cobin, J. (2015). Dasar-dasar Penelitian Kualitatif Tatalangkah Dan Teknik-teknik Teoritisasi Data, Pustaka Pelajar, Yogyakarta.

Subanar, GB. (2010). Manunggaling Kawula-Gusti Dala Transisi; Potret Dunia Jawa dari Yogyakarta. Dalam kumpulan essai "Sesudah Filsafat", cet. 5 Kanisius, 2010), Yogyakarta.

YayasanPawiyatan Kabudayan Karaton Surakarta. (204). Karaton Surakarta, Buku Antar Bangsa, Jakarta, Indonesia. 